\title{
DiscuRso Religioso, LAICIDADE E ESPAÇO PÚBLICO: nOtas Sobre a AtuaÇão Política e MissionáRIa DO PADRE JÚLIO MARIA DE LOMBAERDE (1928-1944)
}

\author{
Religious speech, Laity and Public Space: notes on Political Practice and \\ MISSIONARY FATHER JULIO MARIA DE LOMBAERDE (1928-1944)
}

FABRÍCIO EMERICK SOARES (*)

\begin{abstract}
RESUMO
O presente artigo objetiva ilustrar as interações entre religião, discurso legitimador e formação/transformação do espaço público como marcas das particularidades da laicidade brasileira, discutidas na disciplina de Religiões no Brasil (PPCIR/PPGCSO - ministrada pelo professor Dr. Marcelo Ayres Camurça) e informadas pelos conceitos de "configurações de secularismo e laicidade" (Giumbelli, 2013) e "esfera pública" (Montero, 2012). Nesse sentido, utiliza-se das noções de processo discursivo e fluxos de interações discursivas, como instrumentos para a produção da legitimidade/deslegitimidade dos agentes e instituições religiosas, para analisar os discursos produzidos pelo Padre Júlio Maria De Lombaerde durante sua atuação política e missionária na Paróquia do Senhor Bom Jesus, no município de Manhumirim (1928-1944).
\end{abstract}

PalaVRas-ChaVe: Laicidade. Espaço público. Discurso. Igreja católica.

Abstract

This article aims to illustrate the interactions between religion, legitimizing discourse and formation / transformation of public space as the peculiarities of Brazilian brands of secularism, discussed in the discipline of Religions in Brazil (PPCIR - given by Professor Dr. Marcelo Ayres Camurça) and informed by concepts the "settings secularism and secularism" (Giumbelli, 2013), and "public sphere" (Montero, 2012). In this sense, we use the notions of discursive processes and flows of discursive interactions as instruments for the production of legitimacy / legitimacy agents and religious institutions, to analyze the discourses produced by Father Julio Maria De Lombaerde during his performance at the Parish of the Lord Bom Jesus, in the municipality of Manhumirim (1928-1944).

KEY WORDS: Secularism. Public space. Speech. Catholic church.

\section{INTRODUÇÃO}

No campo da renovação dos estudos sobre a religião e o espaço público, as reflexões sobre a laicidade ocupam lugar privilegiado, pois nos permitem romper com abordagens centradas em modelos e princípios normativos - "modelos heurísticos", para nos oferecerem um referencial analítico capaz de dar conta dos múltiplos processos sociais, políticos e culturais, combinados ao estudo das dinâmicas de

${ }^{(*)}$ Mestre em História Social pela Universidade Severino Sombra USS - Vassouras/RJ. Doutorando em Ciências Sociais pelo PPGCSO-UFJF - orientando do prof. Dr. Marcelo Ayres Camurça Lima. Docente da Faculdade Doctum de Manhuaçu. E-mail: fabricioesoares@bol.com.br 
agentes religiosos, nas suas intercessões com a religião. Nesse caminho, para além de pensar a laicidade somente enquanto o ideal/princípio de separação entre o Estado e a religião, o que nos interessa nesse estudo, é ilustrar as interações entre religião, discurso legitimador e formação/transformação do espaço público como marcas das particularidades da laicidade brasileira.

Para tal empreitada, nos serviremos primeiramente, do conceito de "configurações de secularismo e laicidade" (GIUMBELLI, 2013); que será apresentado e discutido na segunda seção desse estudo, tendo como fio condutor a argumentação de que a laicidade brasileira pode ser compreendida na (re)leitura da conjuntura da própria constituição do Estado republicano, a partir da investigação das especificidades, configurações e dinâmicas próprias dos processos, trajetórias e itinerários de sua realização.

Logo em seguida, na terceira seção, informaremos sobre o conceito de "esfera pública" (MONTERo, 2012); utilizando das noções de processo discursivo e "fluxos de interações discursivas", como instrumentos para a produção da legitimidade/deslegitimidade dos agentes e instituições religiosas; para, na quarta seção desse nosso estudo, analisar os discursos produzidos pelo Padre Júlio Maria De Lombaerde ${ }^{1}$ durante sua atuação na Paróquia do Senhor Bom Jesus, no município de Manhumirim (1928-1944). Tomaremos por marcadores, para a análise das construções discursivas do referido padre, presentes nos registros do Livro de Tombo da Paróquia do Senhor Bom Jesus de Manhumirim e do jornal "O Lutador", além de intercessões com um outro conjunto de construções discursivas, a de seus opositores, expressos no jornal "O Manhumirim”, os seguintes: a ideia de unidade nacional vinculada à igreja católica (“comunidade imaginária nacional”), processos colaborativos entre a igreja católica e o Estado pactuados pelo ideal de "Neocristandade" e expressos em arranjos políticos institucionais; dentre outros. Esses processos e dinâmicas, ao nosso ver, que constituem particularidades da

\footnotetext{
${ }^{1}$ Missionário belga, nascido em 07/01/1878. Ainda jovem entrou na Sociedade dos Missionários da África e em outubro de 1895 partiu para a África. De volta a Europa (1901), iniciou seu noviciado na Novel Congregação Clerical, em 4/10/1902, seguido da emissão dos votos temporários (1903) e votos perpétuos (04/10/1906). Foi ordenado presbítero em 13/06/1908. Em 23 de dezembro de 1912 partiu para missões no Brasil com mais quatro irmãos de congregação. Desembarcou em Recife no dia 15/10/1912, seguindo para Natal/RN e logo depois para Macapá (1913). Após três anos de trabalho em Macapá resolveu fundar as Filhas do Coração Imaculado de Maria (21/11/1916). Com problemas no norte do país e em contato com D. Carloto - bispo de Caratinga - vem para o sudeste do Brasil, chegando em Manhumirim no dia 24/03/1928, tomando posse do respectivo curato em 08/04/1928. Fundou o Instituto dos Missionários Sacramentinos de Nossa Senhora do Santíssimo Sacramento (decreto diocesano de 07/04/1927 - com a vestição dos primeiros padres em 16/03/1929) e também o Instituto das Irmãs Sacramentinas de Nossa Senhora do Santíssimo Sacramento em 25/03/1929. Morreu em Manhumirim, num acidente de automóvel, no dia 24/12/1944.
} 
laicidade brasileira, realmente, não excluíram o elemento religioso católico da “esfera pública”.

Por fim, através da descrição e análise da atuação política e missionária do Padre Júlio Maria De Lombaerde na "esfera pública”, poderemos percebê-la enquanto estratégia de legitimação do mesmo, pois o habilitaram a ser representante da igreja católica, e de seus interesses. Nesse aspecto, a dinâmica que gerou sua legitimidade será identificada, descrita e analisada a partir de um vocabulário simbólico próprio que tanto qualificou a igreja católica como desqualificou os outros universos religiosos e institucionais.

\section{PARTICULARIDADES DA LAICIDADE NO BRASIL}

Segundo Giumbelli (2013), analisar as "configurações de secularismo e laicidade" brasileira, permite mapear e fazer "deslizamentos" sobre os diversos processos de produção e regulação do religioso, a partir das diversas conexões e intercessões entre os agentes religiosos e políticos, por meio dos arranjos políticos e das inúmeras relações da religião no campo social, político e cultural. Permite romper com conceitos normativos e princípios gerais, ou tipos ideais, de modalidades de laicidade que, em tese, poderiam ser comparados entre Estados/nações que teriam se aproximado ou distanciado da regulação do religioso. Permite, também, entender a regulação do religioso em sua aproximação com os próprios aparatos estatais, revelando na inserção jurídico-social das religiões, sua intervenção discursiva na configuração do espaço público.

Dessa maneira, para o entendimento das características particulares da laicidade brasileira, que não exclui o elemento religioso e, no caso específico desse estudo a igreja católica, opta-se pelo conceito de "configurações de secularismo e laicidade", por conter uma amplitude que permite abarcar o conjunto dos mecanismos e dispositivos que atingem os vários grupos religiosos nas suas transformações ao longo de um regime secularista, remetendo para planos de análise que não são contemplados por modelos e princípios (GIUMBELLI, 2013, p. 56); todavia permite também acompanhar as formas e os canais pelos quais se efetiva a relação entre agentes religiosos, enfocados em sua especificidade (confessional $e$ funcional), e os espaços sociais, tais como são historicamente constituídos em uma dada situação (GIUMBELLI, 2013, p. 56).

Avançando na tentativa de mapear a laicidade brasileira, Camurça e Martins (2013), sugerem que, o regime de laicidade é evidenciado pela separação entre a religião e o Estado. Essa separação cria para os cidadãos um espaço neutro e universal 
no qual as pluralidades possam conviver, porém reguladas pelo Estado, estipulando os direitos, as liberdades e as obrigações para a boa convivência. Contudo, isso não representa o desaparecimento, a privatização ou a perda total da influência da religião no espaço público; ao contrário, a presença das religiões no espaço público pode ser percebida no jogo democrático, tanto na política, quanto na influência e discussão/implementação das leis.

Mais especificamente no caso brasileiro, um dos elementos diferenciadores da construção da laicidade, conforme as reflexões de Montero (2013), é que a mesma nasceu com o auxílio/protagonismo da própria igreja católica num contexto de disputas por competências e áreas de influência da hierarquia da própria igreja. Refém do regime do padroado, desde o período colonial e imperial, a igreja católica viu-se progressivamente sobre o domínio do Estado e cada vez mais distante das regulamentações do Vaticano. Nesse contexto, com recursos escassos, poucos padres e com superposições de legislações, originou-se a "Questão Religiosa”, que teve em Don Vital e Don Antônio de Macedo Costa, dois de seus principais expoentes; os mesmos não admitiam a subordinação da instituição a uma estrutura político-estatal dominada por liberais e maçons; fazendo cumprir as determinações apostólicas, que constituíam na expulsão e excomunhão dos maçons das irmandades religiosoas, o conflito tomou dimensões maiores e contornos públicos.

Apesar de ter imprimido na constituinte de 1890 os valores cristãos e defendido sua estrutura autônoma em relação ao Estado, de acordo com Montero (2013), a igreja católica, com a proclamação da república e a constituição de 1891, perdeu seus poderes civis. Entretanto, o catolicismo continuou a se constituir como matéria prima da construção da nacionalidade. Participando amplamente da construção da estrutura do Estado imperial, o catolicismo ofereceu os fundamentos éticos da nação brasileira e, diante dos inúmeros desafios da heterogeneidade populacional, a construção do "cimento imaginário da nação”, por meio da ideia de uma “comunidade imaginária nacional”.

Outro aspecto que marcou a constituição da laicidade brasileira, informado por Mariz (2011), é que, no momento da proclamação da república, o Estado brasileiro não possuia recursos materiais, simbólicos, culturais e sociais para competir com a igreja católica. A mesma, se fazia presente no território nacional de forma mais ampla e ativa que o próprio Estado, tanto por meio de sua estrutura administrativa (paróquias, dioceses etc) como através da educação das elites. Dessa forma, embora o Estado tenha se estabelecido oficialmente separado da igreja católica, concretamente dependia da mesma, vendo-se obrigado a viver num regime de plena integração. 
Prosseguindo na tentativa de oferecer mais elementos para o entendimento das particularidades da laicidade brasileira, são importantes as contribuições de Camurça e Martins (2013) sobre os "fluxos de laicidade". Para os autores, esses "fluxos de laicidade" possuem duas perspectivas distintas: uma no sentido de demarcar a separação mais rígida entre Estado e religião, outra que evidencia a presença da igreja católica na esfera do Estado.

O primeiro fluxo iniciou-se com o advento da república e a constituição de 1891 ao realizar a separação da igreja e do Estado, instituindo a laicização do corpo administrativo e burocrático do mesmo. Nesse momento, as forças civis laicas foram imprimindo no Estado aspectos racionais na direção das áreas que estavam sobre o poder eclesiástico. Passados os primeiros anos da república, a igreja católica passou gradualmente a reivindicar um lugar na política institucional e social do país, devido ao fato de ser a representante da religião majoritária dos brasileiros. Progressivamente foi-se construindo o ideal da "neocristandade", caracterizado por um arranjo entre a igreja católica e o Estado que lhe concedia influências privilegiadas em aparatos ideológicos, tais como, as obras sociais, a orientação da família e a educação formal (CAMURÇA e MARTINS, 2013).

O segundo fluxo, iniciado em 1930, caracterizou-se pelo protagonismo de Don Sebastião Leme frente ao Estado laico. Pela Constituição de 1934, foram asseguradas à igreja católica concessões cruciais pelo Estado no campo da educação religiosa, do financiamento de escolas, seminários e hospitais enquanto "utilidade pública", bem como o reconhecimento do casamento religioso pela lei civil e a proibição do divórcio, dentre outros (Camurça e Martins, 2013).

Também corrobora para o entendimento da laicidade brasileira, especialmente na análise da presença da igreja católica na esfera do Estado, o movimento de "Recristianização/ Romanização" 2. A "Recristianização" do Brasil na década de 1920 caracterizou-se pelo clero assumir uma postura mais enérgica em relação ao avanço da laicidade do Estado brasileiro, bem como “dos inimigos da fé católica”: protestantes, maçons, espíritas, entre outros. Esse movimento exigiu do clero uma atitude militante e, em muitos casos, a aproximação com governos fortes e autoritários.

A imprensa foi uma grande aliada da igreja católica durante o processo de "Recristianização" do Brasil chegando a ser vista como baluarte da defesa das mais sagradas tradições religiosas, meio de divulgação do catolicismo e poderosa arma

\footnotetext{
${ }^{2}$ Segundo Sanchis (1995), a Romanização constituiu-se num "surto de modernidade" e a ação pastoral da
} igreja romanizada deixou "sulcos" profundos de caráter anti-sincrético explícito na religiosidade popular. 
contra os inimigos da Igreja (MATOs, 1990, p. 107). O objetivo principal da imprensa foi divulgar e defender os ideais católicos, bem como alertar a todos sobre os perigos dos “inimigos da religião”. Muitas vezes sua atuação era melhor e mais ofensiva que o próprio púlpito. Dessa forma, houve por parte da hierarquia católica, a criação e defesa da boa imprensa. Nesse sentido:

[...] ao declarar sua aliança com o poder estabelecido no país, a Igreja visava primordialmente garantir a continuidade e o fortalecimento da Restauração Católica, ou seja, uma presença mais expressiva do Catolicismo Romano na vida e na sociedade brasileira...(Azzi, 1980, p. 61). O importante era colocar em evidência que, com exceção da fé católica, as outras denominações religiosas contribuíram apenas para romper a unidade nacional, corromper o povo e atender a interesses de grupos estrangeiros...(Azzi, 1980, p. 65). Em primeiro lugar, convém assinalar que não houve ruptura de continuidade nas relações entre Igreja e Governo com a proclamação do Estado Novo em 1937. A hierarquia católica, que havia conseguido uma série de direitos e privilégios mediante a Constituição de 1934, dispôs-se a continuar a apoiar o regime ditatorial, caso essas conquistas permanecessem inalteradas. Foi o que na realidade sucedeu, pois Vargas sabia que o apoio da Igreja Católica lhe seria muito precioso...(Azzi, 1980, pp. 68-69).

Dessa forma, parece-nos que as particularidades da laicidade brasileira nos possibilitam pensar que, para além do princípio de separação entre Estado e relgião no Brasil, iniciado com o advento da república, o principío da laicidade não excluiu a religião, diga-se a igreja católica. Nessa direção, a laicidade brasileira pode ser compreendida na (re)leitura da conjuntura da própria constituição do Estado republicano, a partir da investigação das especificidades, configurações e dinâmicas próprias dos processos, trajetórias e itinerários de sua realização.

\section{Discurso Religioso e EsPaço PÚblico}

Analisando a relação entre o discurso religioso e a formação do espaço público, Montero (2012) informa que o catolicismo ainda mantém uma primazia social e política, pois as categorias teológicas presentes em suas formas discursivas circulam no imaginário político do país, bem como influenciam outros universos religiosos. De certa forma, pode-se considerar que a proximidade entre o discurso religioso e o espaço estatal, somada à capacidade da igreja de produzir elites, pela educação, constituem-se numa "tecnologia" que, em grande medida, defendeu (e defende) os interesses da mesma, tornando-se elementos da sua legitimidade e capacidade de influenciar na elaboração das leis.

Dessa forma, parece ser claro que a formação da laicidade brasileira passou também pela "esfera pública”. Assim a "esfera pública” não se constitui num espaço 
vazio, mas deve ser tomada enquanto resultado de um fluxo de interações discursivas que carregam as incertezas, as aspirações, os medos $e$ as esperanças de falantes $e$ ouvintes (MONTERO, 2012, p. 176). Para efeitos dos objetivos desse estudo, a noção de "esfera pública" foi tomada enquanto construída pelo "fluxo de interações discursivas", em oposição a outras esferas.

Espera-se que tal abordagem tenha tornado visíveis as relações entre sujeitos de discurso e construir abstratamente um modelo de rede de circulação de categorias e modos de compreendermos a dinâmica dos processos de produção de legitimidade (MONTERO, 2012, p. 177). Isso implicou numa dupla operação, a saber: uma, descrever a dinâmica simbólica que gera a legitimação de um ator ou uma instituição e, outra, compreender os processos de legitimação que se operacionalizam a partir das categorias que circulam na "esfera pública". Sendo assim, o conceito de "controvérsia" não foi entendido como polêmica e divergência, mas como algo que,

permite ao mesmo tempo que se compreendam os processos de mediação no qual as categorias de um campo discursivo se movem para outro, produzindo traduações e, consequentemente, novas significações; que uma multiplicidade de pontos de vista se tornem visíveis e possam ser descritos simultaneamente; e finalmente, que uma variedade de atores, não apenas religiosos, possam ser descritos em sua interação. (MONTERO, 2012, p. 177-178)

Dessa forma, no campo da renovação dos estudos sobre a religião, a laicidade brasileira e a esfera pública, enquanto espaço de "fluxos de interações discursivas", ou seja, processos discursivos de variados atores sociais, nas suas múltiplas interações e busca de legitimidade de seus projetos, a "controvérsia" constitui-se num importante instrumento de identificação, descrição e análise dos agentes e instituições religiosas.

\section{Discurso Religioso, Esfera Pública e Laicidade 3}

O estudo da atuação política e missionária do Padre Júlio Maria De Lombaerde na Paróquia do Senhor Bom Jesus de Manhumirim, no período de 1928 a 1944, serviu para ilustrar o que até o momento chamou-se de processos e dinâmicas da laicidade brasileira, cujas particularidades rompem com os modelos e princípios normativos.

\footnotetext{
3 Parte das informações para a confecção dessa seção do nosso estudo, foram inspiradas na dissertação intitulada: "Do Discurso Missionário à prática do Poder Político: uma análise da atuação do Padre Júlio Maria De Lombaerde na Paróquia do Senhor Bom Jesus de Manhumirim - 1928 a 1944" e nas atuais pesquisas constantes no projeto de tese intitulado: "Limtes e Possibilidades de uma Vida Democrática na formação social de Manhumirim sob o viés da Cultura Política Católica: uma análise comparativa das intenções, desenvolvimento e efeitos da ação religiosa e política dos Padres Júlio Maria De Lombaerde (1928-1944) e Ronaldo Lopes Corrêa (1999-2012)”.
} 
Na construção discursiva do Padre Júlio Maria De Lombaerde, presente nos registros do Livro de Tombo4 da Paróquia do Senhor Bom Jesus de Manhumirim e do jornal "O Lutador", pode-se perceber, dentre outros, os seguintes marcadores: a ideia de unidade nacional vinculada à igreja católica ("comunidade imaginária nacional”), processos colaborativos entre a igreja católica e o Estado pactuados pelo ideal de "Neocristandade" e expressos em arranjos políticos institucionais. Esses processos e dinâmicas sugerem que as particularidades da laicidade brasileira, realmente, não excluíram o elemento religioso católico da "esfera pública”.

Assim, enfatizou-se a descrição da atuação política e missionária do Padre Júlio Maria De Lombaerde na "esfera pública” como estratégia de legitimação desse agente, pois o habilitaram a ser representante da igreja católica, e de seus interesses, frente aos outros universos religiosos e institucionais. Nesse aspecto, a dinâmica (enquanto categorias de circulação) que gerou sua legitimidade foi identificada, descrita e analisada a partir de um vocabulário simbólico próprio que tanto qualificou a igreja católica como desqualificou os outros universos religiosos e institucionais.

Veja-se, pois, o que as formações discursivas (fontes) informaram sobre as atividades do Padre Júlio Maria De Lombaerde, na Paróquia do Senhor Bom Jesus de Manhumirim:

Retardei até janeiro deste anno a escricturaçaõ do Livro de Tombo, para ter o tempo de observar e estudar o povo e a situação, e não adiantar nada de duvidoso ou de incerto. É pois após 9 mezes de residência e de trabalhos que julgo a situação e os factos da parochia (...) Passei na casa parochial, junto com o Vigário, a Semana Santa, constatando com tristesa que o povo estava completamente imbuído de idéias protestantes, freqüentando poucos e pouco a igreja, e de nenhum modo os sacramentos. O protestantismo solidamente implantado $e$ protegido por uns ricos, possuía dois templos um de presbiterianos e outro de Baptistas, funcionando um terceiro os Evangelistas e em casa particular. Nenhuma irmandade canonicamente erigida existia. Encontrei umas 15 senhoras com a fita do Coração de Jesus, fazendo a comunhão mensal no $1^{\circ}$ Domingo; também umas 18 Filhas de Maria, que nem appareceram no princípio, sendo apenas a fita e o véu, sem organização nenhuma. O catecismo das creanças não existia, nem havia pregação, de modo que reinava a mais completa ignorância religiosa..$^{5}$

\footnotetext{
4 O Livro de Tombo da Paróquia do Senhor Bom Jesus é uma fonte primária, manuscrita, pertencente ao acervo do escritório paroquial e cuja pertinência para a realização de nossas pesquisas está no fato de narrar, senão todos, os principais acontecimentos e ações tomadas pelo pároco - Padre Júlio Maria De Lombaerde - durante o ano, a saber: atuação frente ao avanço do protestantismo e da maçonaria, fundação de irmandades e desenvolvimento da religião católica, registros de construção de suas obras assistenciais, como o Colégio Santa Teresinha, Ginásio Pio XI, Seminário Apostólico e Hospital São Vicente de Paulo, embates com o então prefeito Dr. Alfredo Lima, contatos e articulações com bispos da região e políticos locais, além de impressões sobre a cidade de Manhumirim, sua cultura e população.

5 Livro de Tombo da Paróquia do Senhor Bom Jesus de Manhumirim, f. 9 verso.
} 
A situação encontrada pelo Padre Júlio Maria De Lombaerde foi de um lado, uma população católica desbaratada, sem liderança espiritual, dormindo na mais "completa ignorância religiosa", pois quase não havia freqüência à igreja e aos sacramentos, além de inexistirem, oficialmente, os movimentos religiosos capazes de agregar os leigos, de outro lado, um protestantismo "solidamente implantado e protegido por uns ricos".

Pode-se considerar que naquele momento o Padre Júlio Maria De Lombaerde viu-se frente a uma situação que se apresentou propícia para iniciar sua atuação missionária de "Recristianização" e, por meio do sacerdócio militante e da reorganização da sociedade, reconquistar o espaço sócio-político perdido para as religiões protestantes e outros grupos como, por exemplo, a maçonaria.

Na continuidade dos registros de sua observação/análise e do "estudo do povo e da situação”, o Padre Júlio Maria De Lombaerde pareceu confirmar a debilidade, a falta de preparo e a iniciativa do clero à frente dos trabalhos da igreja, na Paróquia do Senhor Bom Jesus, naquele momento:

O Padre Frederico, Hespanhol e falando bastante mal o portuguez, era um sacerdote piedoso e exemplar, de optimos costumes, que procurou melhorar a situação. De temperamento pacífico e querendo a paz com todos, receava declarar a guerra aos protestantes, e chamar a attenção do povo sobre os abusos. Dessa falta de iniciativa resultava necessariamente a diminuição da fé $e a$ invasão do erro. ${ }^{6}$

Parece que no propósito de legitimar-se, o Padre Júlio Maria De Lombaerde identificou que parte da dificuldade e do despreparo do sacerdote que o antecedeu estava na comunicação verbal, pois ele falava "bastante mal o portuguez" e, apesar do Padre La Barrera reunir atributos necessários à prática do bom sacerdócio, tais como, a piedade e o exemplo nos costumes, faltavam-lhe outros tão ou mais importantes como, por exemplo, o espírito aguerrido capaz de não só “declarar a guerra aos protestantes”, mas de chamar a atenção o povo.

Chamou-nos a atenção nesse mesmo registro, o uso da expressão "invasão do erro" que pareceu-nos ilustrar bem a ideia de legitimar-se, deslegitimando os outros universos/manifestações religiosas e instituições. Nesse sentido, o discurso religioso construído pelo Padre Júlio Maria De Lombaerde encarregou-se de reafirmar no espaço público o princípio da "única verdade”, ou seja, o do catolicismo como a única expressão da verdade da fé.

\footnotetext{
${ }^{6}$ Livro de Tombo da Paróquia do Senhor Bom Jesus de Manhumirim, f. 9 verso.
} 
Uma vez à frente dos trabalhos da igreja católica, no Curato do Bom Jesus do Pirapetinga, o Padre Júlio Maria De Lombaerde, tratou logo de colocar a "casa em ordem":

[...] tendo tomado posse da parochia esperei a hora opportuna para agir, provocando-a durante a pregação do mês de Maria. O resultado não se fez esperar. Os protestantes desesperados pela enorme concorrência do mês Mariano e o enthusiasmo dos Cathólicos, espalharam um Bolletim contendo diversas objecçoes contra a religião, e mandaram vir uns pastores de fora, para pregar nas ruas. Tomei a defensiva e ataqueio-os_resolutamente em conferencias públicas e pelo jornal "Manhumirim". O resultado foi extra-ordinário. A egreja encheu-se o jornal duplicou a tiragem, e apesar da resistência tenaz dos Pastores, a verdade foi vencendo todos os obstáculos. Cahiram me nas costas uns 5 pastores, com artigos e folhetos, respondi a todos, esmagando-os um por um e obrigando-os à uma retirada vergonhosa. A opinião pública foi conquistada em favor da verdade. Muitos protestantes voltaram ao seio da egreja e outros retiraram-se, de modo a deixar o campo vasio. Sobre as ruínas do espírito protestante fundei e organisei a Liga Catholica dos homens, o Apostolado, as Filhas de Maria, a Cruzada eucharistica, e o cathechismo, e por fim fundei o Lutador para manter a direcção e não deixar refriar o catholicismo[...] Hoje o triunfo é completo. O templo baptista fechou por falta de frquencia - o evangélico seguiu de perto e o Presbyteriano está em completa decadência. Em vez de uma freqüência de 200 pessoas que contava está reduzido a uma freqüência de 15 a 20 pessoas. Os outros envergonham-se de freqüentar o templo ou voltaram a religião catholica7.

Nesse trecho nota-se especialmente nas palavras e termos grifados, a construção de um discurso que, simultaneamente, objetivou legitimar seu autor e suas ações como representantes de um propósito maior, ou seja, da ação combativa da igreja católica, expressada por um vocabulário de guerra. Foi, portanto, um discurso guerreiro que caracterizou toda a construção discursiva do Padre Júlio Maria De Lombaerde, seja nos registros do Livro de Tombo, seja nos artigos publicados pelo jornal "O Lutador".

No registro acima foi possível esquadrinhar algumas estratégias, das quais se serviu o Padre Júlio Maria De Lombaerde para legitimar-se e empreender sua campanha de conquista e reconquista dos fiéis católicos e dos ditos protestantes e para (re) afirmar no fluxo dos discursos a própria importância sócio-política da igreja católica.

Abaixo, transcreve-se um longo trecho do livro de Tombo que continuou reforçando a ideia de que a igreja possuiu "inimigos da religião" que também divulgavam seus propósitos, valores e orientações sociais, cujo Padre Júlio Maria De Lombaerde tratou de desqualificar:

7 Livro de Tombo da Paróquia do Senhor Bom Jesus de Manhumirim, f. 10. 
Estes dois anos tem sido dois annos de lucta sem trégua, contra os inimigos da religião e de esforço para o levantamento espiritual das almas. O protestantismo desmoralisado e derrotado procurou um apoio na maçonaria e desta união surgiu nova lucta religiosa. A maçonaria embora quieta e escondida constituia uma verdadeira força na cidade, contando 127 homens, todos elles de classe abastada e chefiada pelo Vice-presidente da Comarca: Manoel Manduca, um vereador: Dr. Caciquinha e o próprio presidente Dr. Alfredo Lima. Todos os empregados públicos eram maçons e diversos pertenciam à Liga Cathólica. A Maçonaria resolveu construir a sua Loja, e para esse fim adquiriu um terreno ao pé da Matriz do Bom Jesus. Sciente do propósito de ali levantar a maçonaria chamei em particular o Venerável Manoel Manduca e Dr. Caciquinha, pedindolhes, como amigos, que não fizessem tal, pois parecia um affronto, uma provocação a egreja catholica. Prometteram empenhar se, porém nada fizeram e deliberaram que a Loja seria feita ali mesmo. Protestei publicamente na egreja e pelo jornal estando a população inteira ao meu lado. Mandei um officio de protesto à Maçonaria, porém sem resultado. Neste ínterim, descubri nos livros do patrimônio que a escriptura da posse tinha sido falsificada e que tinham quasi duplicado a area de terreno adequirida, de modo que o prédio estava pela metade no terreno da egreja. Protestei de novo, não atenderam, e as obras continuaram. Chamei então os advogados Adhemar Távora e Edgar Toledo que examinaram o caso demonstraram a falsificação. Então a maçonaria desistiu e vendeu o prédio começado à Câmara. A questão foi resolvida, porém, os maçons humilhados, envergonhados procuraram a todo custo uma desfora de vinganças. Começou então uma serie de perseguições, ataques, calunnias, etc ${ }^{8}$.

Os registros sugerem haver um triunfalismo guerreiro acerca dos desmontes e embates contínuos com os protestantes e outras forças e grupos locais, pois, neles, o Padre Júlio Maria De Lombaerde reconheceu que maçonaria, embora "escondida" representava uma força na comunidade capaz de fazer frente aos seus interesses. Contudo, não poderia ser declarada expressamente como inimiga da igreja católica, pois muitos de seus adeptos freqüentavam a liga católica fundada por ele. No entanto, quando a maçonaria aceitou os protestantes, houve uma digressão dos fluxos discursivos do Padre Júlio Maria De Lombaerde que passou a desqualificar também a maçonaria declarando-a uma inimiga pública da religião.

Por meio dos protestos no jornal "O Lutador", o Padre Júlio Maria De Lombaerde iniciou uma "nova luta religiosa", mas cujos contornos ficaram mais nítidos. Assim, para além do campo religioso, as ações do sacerdote perpassaram para os campos do social e do político e os "inimigos" passaram a ser identificados. Deixando de serem somente protestantes ou maçons, tornaram-se indivíduos investidos de poder e prestígio na sociedade, tais como, o Dr. Caciquinha, Manoel Manduca e Dr. Alfredo Lima, que ocupavam cargos importantes no legislativo local: o primeiro era vereador, o segundo, vice-presidente da câmara, e o terceiro, presidente.

${ }^{8}$ Livro de Tombo da Paróquia do Senhor Bom Jesus de Manhumirim, f. 13 verso. 
Desde então, os embates tornaram-se cada vez mais frequentes e revelavam sua face política, como pode-se notar no trecho abaixo:

Aproveitaram da revolução para fazer todos os absurdos; chegaram a tomar as machinas de typographia, quebraram tudo, queimaram os jornais. Um bando de capangas chefiado pelos assassinos José Porcino e Alvim, sempre sobre ordens de Dr. Alfredo Lima, Manoel Manduca e Pedro Nolasco. Um dia o furor maçônico de Dr. Alfredo chegou ao ponto de esperar me da descida do trem para defeitear-me, e não tendo podido fazel-o, foi no Collegio, onde derramou toda a bílis, insultando e praguejando depois de se ter entregue ao excesso de bebida. Outro dia bombardearam o Collegio de Sta. Therezinha com mais de 200 bombas e foguetes, quebrando quantidade de telhas No dia 7 de Dezembro de 1930 chegou o furou ao auge; Porcino com seus 10 capangas foi atacar a egreja, na ocasião da missa das 9 horas devendo ser matado à porta da egreja o sr. Julio Rabello, e assassinado no Altar o Padre Júlio Maria. $\mathrm{O}$ ataque deu-se.. houve tiroteio, porém o plano sahindo mal; não chegaram a matar ninguém. Todos os pormenores destas barbaridades estam descriptos no "O Lutador" cujo número ficará archivado. De combinação com o Exmo. Sr. Bispo D. Carloto, tomei a frente de uma reacção energica, e sem entrar diretamente no movimento político, organisei os elementos de valor, no fim de formar a base de uma política catholica. ${ }^{9}$

Embora não se tenha tido acesso a nenhum jornal que retratasse em notícias os acontecimentos da revolução, encontrou-se no livro do Padre Demerval Alves Botelho algumas pistas. Devido à Revolução de 30 houve um clima de instabilidade na cidade por causa da retirada da polícia para integrar as forças revolucionárias. Assim, a guarda da cidade ficou a cargo de homens contratados pelo presidente da câmara. As notícias que chegavam a Manhumirim foram filtradas e controladas. Com isso, a população ficou desinformada e temerosa sobre o que poderia, de fato, estar acontecendo.

A fim de divulgar os acontecimentos reais, o Padre Júlio Maria De Lombaerde conseguiu um mensageiro de confiança e passou a publicar em seu jornal, o Lutador, o que de fato acontecia. Seus adversários lançaram-se contra ele e, conforme o padre escreveu, aproveitaram-se da ausência de forças policiais - ou da conivência dessas com as lideranças políticas - para destruir sua tipografia.

Fica sugerido que o Padre Júlio Maria De Lombaerde aproveitou desse episódio para outra vez desqualificar/deslegitimar seus adversários chamando-os de "bando de baderneiros" que, sem nenhuma diplomacia tentavam fazer valer suas causas, utilizando-se de violência física e verbal. Igualmente, serviu-se do episódio para legitimar-se, diferenciando-se dos demais por buscar sempre a legalidade para resolver as querelas com seus opositores.

${ }^{9}$ Livro de Tombo da Paróquia do Senhor Bom Jesus de Manhumirim, f. 14. 
Mesmo afirmando não entrar diretamente na política, a partir do episódio narrado, o Padre Júlio Maria De Lombaerde, procurou aglutinar em seu entorno indivíduos católicos de influência local e lançou mão da proximidade da igreja católica junto ao Estado ("Neocristandade"). Assim, reuniu um grupo de indivíduos para formar uma base política católica, sugerindo a ideia de tratar-se de uma posição de defesa da religião que representava. No entanto, a sequência dos registros possibilita reconhecer que seus propósitos iam muito além das questões religiosas:

Munido da recomendação de D. Carloto e acompanhado por Monsenhor Gonsalez, fui apresentar e expor o caso ao Dr. Arthur Bernardes, em Viçosa, que prometeu tomar as providencias e destituir a política de Manhumirim. Assim foi feito: alcancei a nomeação de um chefe político catholico: Sr. Narciso Rabelo, a vinda de um Prefeito Catholico, e de um tenente do exercito para manter a ordem. A política do Dr. Alfredo Lima ficou deste modo derrubada e o povo ficou enthusiasmado pela nova direção das cousas. A maçonaria desmantelou-se por completo; ficando reduzida à metade. Mais um esforço e espero que a seita codennada desaparecerá de Manhumirim, para ceder o lugar a um único rebanho, que é o de Jesus Cristo. A vitória está alcançada; falta agora approveital-a, e não deixar mais entrar no governo nenhum maçon, nem nenhum protestante ${ }^{10}$.

Foi, em 1934, por meio da fundação de um jornal semanário, "O Lutador”, que o Padre Júlio Maria De Lombaerde, tornou público os seus fluxos discursivos e atingiu um número significativo da população local, ao deslocar o espaço da discussão e circulação das ideias para um instrumento mais amplo que o templo católico. Assim, as pessoas mesmo não freqüentando a igreja católica puderam acompanhar o desenrolar das intercessões e interções discursivas pelos jornais.

Uma edição do semanário ${ }^{11}$ divulgou um artigo de quatro páginas, praticamente todo o jornal, dedicado a rebater provocações lançadas ao Padre Júlio Maria De Lombaerde, intitulado "Antes de tudo... mentira: resposta ao jornal "o Evangelista”. Noutra edição, por ocasião do fechamento das lojas maçônicas, em outubro de 1937, pelo governo federal, o Padre Júlio Maria De Lombaerde estampou matéria de primeira página com o título Fechada a Maçonaria! O Grande Oriente "abateu columna" - o perigo continua, divulgando e comemorando a atitude governamental.

Apesar de ter celebrado o fechamento das lojas maçônicas no Brasil, e por extensão em Manhumirim, como o maior acontecimento promovido pelo governo, observou-se pelo título da matéria que, mesmo fechada por decreto federal, a loja

${ }^{10}$ Livro de Tombo da Paróquia do Senhor Bom Jesus de Manhumirim, f. 14 verso.

${ }^{11}$ Jornal O Lutador, edição de 28 de janeiro de 1934. 
maçônica continuou representando perigo aos interesses católicos, pois em Manhumirim, segundo o padre, a loja deu abrigo aos protestantes e congregou importantes figuras de prestigio político local.

O episódio de fechamento das lojas maçônicas refletiu a proximidade entre igreja e Estado, como uma característica da laicidade brasileira, pois, no geral, a maçonaria foi considerada inimiga da verdade e da religião católica. Por outro lado, refletiu, também, a legitimidade do Padre Júlio Maria De Lombaerde, construída em seus discursos, que demonstraram que os inimigos da religião estavam sendo punidos e castigados por Deus, pois perseguiram a religião católica.

Para o padre, em Manhumirim, não só a instituição recebeu seus castigos, mas também seus dirigentes estavam sendo punidos, pois

o maior acontecimento deste mez de outubro, e até um dos maiores e mais significativos que o Governo já realizou, é sem dúvida o fechamento das lojas maçônicas, reconhecidas como centro de communismo (...) Em Manhumirim, o povo conhece bastante o que é a tal maçonaria, o que deseja, o que faz... Quantas calamidades ella tem espalhado em Manhumirim!... Mas também quantos castigos ella já recebeu de Deus. Passem em revista os taes heroes do triangulo e seus emissarios desde aquelle advogado que assignou, na revolução, a violação de domicilio e a profanação das imagens dos santos, até o ultimo que defendeu o processo maçônico contra o Collegio das Religiosas. O primeiro já deixou este mundo, e dizem que o segundo já está tuberculoso numa casa de saúde. E entre os dois, quantos outros já receberam o pagamento de suas obras!12

Para ele, se fez simultaneamente a "justiça dos homens" pela mão do governo, e a justiça de Deus.

$\mathrm{Na}$ edição do jornal de 25 de março de 1934 encontrou-se referências ao episódio de destruição das máquinas de tipografia do jornal pelos maçons, mencionado no livro de Tombo, nos anos de 1929 e 1930. Com o título de O Lutador resuscitado! o texto foi uma justificativa aos leitores sobre o desapparecimento do Lutador do theatro da luta ${ }^{13}$. O texto mereceu ser destacado, pois sugeriu que, mesmo tendo perdido uma batalha para seus opositores, o padre conseguiu confirmar a proximidade da Igreja com o Estado.

Conforme já havia registrado no Livro de Tombo, por causa da legitimidade que construiu, o Padre Júlio Maria De Lombaerde, conseguiu a nomeação de indivíduos católicos praticantes, tanto moradores locais como vindos de fora, para os

\footnotetext{
12 Jornal O Lutador, edição de outubro de 1937.

13 Jornal O Lutador, edição de 25 de março de 1934.
} 
cargos políticos do município, junto ao então presidente, Arthur Bernardes. Assim, nas palavras do próprio padre

[...] graças a Deus e mercê à acção moralizadora, energica e patriótica do incomparável e eminente Mineiro, Dr. Arthur Bernardes, Manhumirim readquiriu a paz, a concórdia, a perfeita união de seus filhos. Os elementos pertubadores, desordeiros do Município, em justo castigo de seus erros e bravatas, foram exonerados e substituído por elementos de escol, que podem garantir e realizar a paz e a felicidade da população._O Dr. Alfredo Lima, de tristissima memória, com a caterva de sequazes, que o cercavam, foi demitido e para sempre alijado da política, que descaradamente deshonrava, e hoje os destinos do nosso Município estão entregues nas mãos de um homem a quem todos veneram e estima, por ser homem de bem em toda a extenção da palavra; homem de progresso, de justiça, de consummada prudência, homem de fé. Sim, o Sr. Narciso Rabelo, de quem queremos fallar, foi nomeado Chefe político do Município, tendo a seu lado o sr. Américo Toledo, outro elemento digno de todos os encômios, por sua dignidade, honradez e espírito progressista. O novo Prefeito Municipal, o digníssimo Dr. Nelson César Pereira da Silva é um moço de raras e exepcionaes [...] de visão e de conhecimentos administrativos práticos, além de ser um catholico praticante, decidido, de acção e soccio da Liga Catholica. (...) Com taes predicados o novo Prefeito encontrará em Manhumirim, como em cada uma de suas famílias, uma ampla e cordial sympathia, o auxilio e boa vontade de todos para felicíssimo e fecundo governo. Com catholico praticante e de acção saberá na sua douta e esclarecida prudência, sanar e remediar os males aqui feitos pela nefanda seita maçônica, que empurrava e dirigia o Dr. Alfredo Lima, fraco catholico e só de nome, tornado o protector dos que, de qualquer modo, têm combatido aqui a egreja chatholica, a única propulsora do progresso deste logar, [...] Como o sr. Prefeito, é o nosso digníssimo Delegado também um catholico praticante, convencido e igualmente sócio da Liga Catholica. Elle saberá manter com punho férreo se preciso, entre todos nós a união e a paz, e extinguirá impiedosamente e por completo o cangaceirismo que nos infesta com desordeiros e criminosos, que ultimamente têm implantado o terror e desassocego em nossa sociedade pacata e ordeira $[. . .]^{14}$.

À época, "O Manhumirim" foi o jornal oficial da prefeitura municipal e se encarregou de fazer circular as ideias dos opositores do Padre Júlio Maria De Lombaerde, bem como rebater os ataques e atacar ao padre e seus seguidores. Em alguns de seus exemplares encontrou-se as "controvérsias" ao fluxo discursivo da igreja católica, com a finalidade de desqualificação da mesma.

Na edição de 02 de abril de 1933, há uma matéria que objetivou atacar ao Padre Júlio Maria De Lombaerde, denunciando sua intromissão nas coisas da política. $\mathrm{O}$ texto, assinado por Manoel Bernardes, procurou definir claramente a finalidade e os limites de ação do clero:

O intromettimento do Clero nos negócios públicos, - e é um catholico de verdade quem falla - destoa completamente do verdadeiro sentimento que deve presidir a

14 Jornal O Lutador, edição de 25 de março de 1934. 
alma religiosa do Brasil [...] O papel do clero brasileiro nestas horas de afflição para este bocado de mundo sagrado, é no altar, aos pés de Jesús Sacramentado, implorando ao Pai muito querido, com fervor, com amor e absoluta confiança, sentimentos bons para os homens que têm de governar o Brasil e não nos palanques públicos, desviando o coração de seus parochianos para a política da terra, enfraquecendo-lhes $[\ldots]^{15}$

Escrito por alguém que disse ser "um católico de verdade”, a ideia defendida foi na contramão das diretrizes da atuação da igreja católica no Brasil, a partir da década de 20, e confirmada, na década de 30, pelo movimento de "Recristianização", pactuado pelo ideal da "Neocristandade"

No mesmo mês e ano, o jornal publicou uma matéria na qual o Dr. Alfredo Lima, prefeito à época, dirigindo-se a D. Carloto, Bispo Diocesano, explicou um "mal entendido" entre seus correligionários e o Dr. Aldo Prado, suposto presidente da liga eleitoral catholica e, provavelmente, vinculado ao Padre Júlio Maria De Lombaerde. O Dr. Aldo Prado, em carta ao bispo, informou estar correndo perigo de morte pelo Dr. Alfredo Lima e seus amigos porque lhe fazia oposição. $\mathrm{O}$ trecho da carta ao bispo foi assim publicado,

"Dr. ALDO PRADO, presidente da Liga Eleitoral Catholica, que tem qualificado numerosos eleitores catholicos, será eliminado pelos assassinos que cercam o prefeito, si Vossencia não tomar enérgicas providências... Confio Vossencia não protegerá assassinos, embora politicamente seus amigos". ${ }^{16}$

Essa denúncia sugere estarem em jogo, além das questões de amizades, as posições políticas. O Dr. Aldo Prado apelou ao bispo para proteger-lhe, pois se considerou um representante dos interesses do catolicismo ameaçado pelo Dr. Alfredo Lima e seus correligionários na cidade, estando por esse motivo qualificando numerosos eleitores católicos. Para "deslegitimar" a posição assumida pelo Dr. Aldo Prado, o Dr. Alfredo Lima escreveu no jornal que,

[...] nesse comunicado telegraphico, expedido, não daqui, onde os factos se desenrolam, mas de Caratinga, onde a noticia delles deve chegar com os accréscimos recebidos em viagem, s.exc. o sr. dom Carloto começa por me accusar de não querer opposição nem eleitores catholicos. Antes de tudo, sem desrespeito por s. exc., eu terei de observar que a accusação é visivelmente oca, embora lançada de tão alto. Si o eleitorado municipal, numa proporção de 90 por cento, está declaradamente, a meu lado, e secunda a minha acção política, acho razoável admittir-se que no meu partido e sob a minha orientação, há uma ponderabilissima percentagem de eleitores catholicos [...] E para mostrar como é imperdoável a minha hostilidade aos eleitores catholicos, o senhor bispo dom Carloto escreve, com toda as letras, que padre Julio não faz política. [...] Ainda

\footnotetext{
15 Jornal “Manhumirim”, edição de 2 de abril de 1933.
}

16 Jornal "Manhumirim", edição de 27 de abril de 1933. 
mais. Sabe, convencidamente, s. exc. o sr. bispo que o dr. Aldo Prado não é o presidente da Liga Catholica local. Esta honraria lhe está sendo atribuída para armar ao effeito e para colorir a perseguição de que lhe queixa. Presidente da Liga é o nosso digno concidadão, sr. Anselmo Gomes Campos, figura de relevo no commercio e na industria do município ${ }^{17}$.

Na edição de novembro de 1937 de "O Manhumirim" encontrou-se outro exemplo das intercessões dos fluxos discursivos no espaço público, no sentido de desqualificar e deslegitimar sujeitos e instituições em posições opostas. Assim, ao texto comemorativo sobre o fechamento das lojas maçonicas, escrito pelo Padre Júlio Maria De Lombaerde, sob o título de Em defesa da memória de um amigo escreveu-se que

[...] o jornaleco "O Lutador", que se edita nesta cidade, sob a direcção do Padre Júlio Maria, em seu numero de Ourtubro p.p., falando accerca do fechamento da Maçonaria, fez allusão a uma passagem, cujas personagens ficaram desde logo, patenteadas aos olhos dos que conhecem a vida local como se referindo ao saudoso Dr. Vasco Soares de Moura e ao jovem causídico Dr. Carlos Soares de Moura. Disse que "o primeiro já deixou este mundo", e o "segundo já está tuberculoso numa casa de saúde". Vislumbra-se nas entrelinhas do trecho a que nos referimos a satisfação do aludido mensário por esse infausto acontecimento. É lamentável que um periódico, dirigido por um sacerdote, ao envez de ter palavras de conforto, em taes casos, sahia em campo vangloriando por um facto dessa naturesa. (...) Em nosso nome, portanto, e no do povo manhumiriense, protestamos energicamente contra esse gesto do Pe. Júlio Maria [... ${ }^{18}$

Em outras edições dos jornais "O Lutador" e "O Manhumirim" encontrou-se a descrição de episódios que ilustram como as interações/intercessões discursivas podem atuar na legitimidade/deslegitimidade de agentes e instituições, bem como na construção, desconstrução e reconstrução dos espaços públicos. Contudo, os limites dessa modalidade de escrita acadêmica não permitem apresentá-los. Dessa maneira, espera-se que os recortes selecionados tenham sido suficientes para a ilustração que se pretendeu fazer.

\section{CONSIDERAÇÕES FINAIS}

À guisa de considerações finais, reiteramos que o propósito desse estudo foi ilustrar as interações entre religião, discurso legitimador e formação/transformação do espaço público como marcas das particularidades da laicidade brasileira. Dentre essas particularidades, ressalta-se que vários episódios da nossa história revelam que o princípio de separação entre Estado e igreja, iniciado com o advento da república, não

\footnotetext{
17 Jornal "Manhumirim", edição de 27 de abril de 1933.

18 Jornal "Manhumirim”, edição de 7 de novembro de 1937.
} 
excluiu a religião católica, ou outras manifestações religiosas, nem seus representantes e portadores de seus discursos.

Reitera-se a utilização das noções de processo discursivo e "fluxos de interações discursivas”, como instrumentos para a produção da legitimidade/deslegitimidade dos sujeitos e instituições religiosas para reconhecer, identificar e analisar os discursos e ações produzidos pelo Padre Júlio Maria De Lombaerde durante sua atuação política e missionária na paróquia do Senhor Bom Jesus, no município de Manhumirim, no período de 1928 a 1944.

De fato, o Padre Júlio Maria De Lombaerde representou o espírito missionário da igreja católica de sua época, tendo em vista sua atuação em três continentes África, Europa e América. No Brasil, sua presença mais especificamente no sudeste, na cidade de Manhumirim, revelou, por meio de seus discursos e ações, sua legitimidade como portador das diretrizes da "Recristianização", pelas quais somente a igreja católica seria capaz de (re) organizar a sociedade, restabelecer-lhe a ordem e a moral, pois era a única portadora da verdade.

Por fim, reforça-se que as articulações políticas do Padre Júlio Maria De Lombaerde para conseguir a nomeação de chefes de governo local católicos, expressaram as ações de um agente que, por meio de seus discursos, construiu-se como legítimo representante de uma ordem social ameaçada, mais por adversários religiosos, ou seja, protestantes e maçons, e menos por adversários políticos. Tal fato sintonizou-se com uma historicidade particular que no Brasil envolveu a igreja católica e o Estado, numa conjuntura de laicidade, que, ao contrário de outros Estados, permitiu a proximidade/colaboração entre essas instituições.

\section{REFERÊNCIAS}

AZZI, Riolando. A Igreja Católica no Brasil durante o Estado Novo (1937-1945). In:

Síntese Nova Fase VII (1980), n ${ }^{\circ}$ 19, p.49-71.

CAMURÇA, Marcelo Ayres; MARTINS, Sueli. Sobre a permanência e a naturalização do catolicismo na esfera pública no Brasil: o caso de uma escola municipal. Cultura y Religión, vol. VII, $\mathrm{n}^{0}$ 2, 2013, p.102-116.

GIUMBELLI, Emerson. Para estudar a laicidade, procure o religioso. In: Verônica GIMÉNEZ, Verônica e GIUMBELL, Emerson (Orgs.). Religion, Cultura e política em las Sociedades del signo XXI. Buenos Aires: Biblos, 2013. p. 43-68.

. O que é um ambiente laico? Espaços (inter) religiosos em instituições públicas. Cultura y Religion, vol. 07, $\mathrm{n}^{0}$ 2, 2013, p.32-47. MATOS, Henrique Cristiano José. Um estudo histórico sobre o catolicismo militante em Minas, entre 1922 e 1936. Belo Horizonte: O Lutador, 1990. 
MARIZ, Cecília. Algumas reflexões sobre a religião e luta pela cidadania. In: BURITY, Joanildo e ANDRADE, Péricles (Orgs). Religião e Cidadania. São Cristóvão: Ed. UFS, Recife: Fundação Joaquim Nabuco, 2011, p. 263-272.

MONTERO, Paula. Religião, Laicidade e Secularismo: Um debate contemporâneo à luz do caso brasileiro. Cultura y Religión, vol. VII, nº 2, 2013, p.13-31.

. "Controvérsias religiosas e esfera pública: repensando a religião como

discurso”. Religião e Sociedade, 2012/1, p. 167-183.

SANCHIS, Pierre. O campo religioso será ainda hoje o campo das religiões? (Sub-itens 2 e 3). In: HOORNAERT, Eduardo (Org.). História da Igreja na América Latina e no Caribe: o debate metodológico. Petrópolis: Vozes, 1995, p. 96-131.

SOARES, Fabrício Emerick. Do Discurso Missionário a Prática do Poder

Político: uma análise da atuação do Padre Júlio Maria de Lombaerde na Paróquia do Senhor Bom Jesus de Manhumirim - 1928 a 1944. 2009, 109 f. Dissertação (Mestrado em História Social) - Universidade Severino Sombra, Vassouras, 2009.

Recebido em 19/o1/2015 Aprovado em 03/05/2015 